\title{
Direct Evidence of Endophyte (Neotyphodium coenophialum) Genotype Effect on Growth and Vertical Transmission of Endophyte in Tall Fescue (Schedonorus phoenix Scop.) Under Water Stress
}

\author{
Ho-Jong Ju* \\ Department of Agricultural Biology, Institute Agricultural Science \& Technology, Plant Medicinal Research Center, Chonbuk \\ National University, Jeonju 561-756, Korea \\ (Received on May 26, 2011; Revised on July 25, 2011; Accepted on July 26, 2011)
}

Tall fescue (Schedonorus phoenix Scop.) is resistant to abiotic and biotic stresses through a symbiotic relationship with Neotyphodium coenophialum. However, this endophyte has been considered detrimental since it produces toxic alkaloids to animals. It is vital to understand mutuality between these two to maximize positive impact of the endophyte on agri-ecosystem. Little research has been conducted on endophyte transmission mechanism in planta. To provide basic information related to endophyte transmission, an experiment was conducted to examine the effect of endophyte genotype and water stress on endophyte transmission by imposing soil moisture deficits at different stages of panicle development. There was water stress effect on endophyte frequency but not on concentration, whereas endophyte genotype significantly influenced endophyte concentration in pseudostem of tall fescue at boot stage. Reproductive tillers showed greater endophyte frequency and concentration. Endophyte frequency in florets or seeds depended on position within panicle. There was no drought effect on endophyte concentration, but showed the effect of endophyte genotype on endophyte concentration in florets and seeds. Overall endophyte concentration in seeds was higher. From this study, we may conclude that although water stress reduced endophyte frequency in vegetative tiller, water stress does not have effect on endophyte transmission, suggesting that drought is not an important factor controlling the endophyte transmission from plant to seed. Endophyte genotype and seed position in a panicle affected endophyte transmission, indicating that these two factors are involved in endophyte transmission and may determine seed transmission of endophyte in tall fescue.

Keywords : endophyte genotype, endophyte transmission, Neotyphodium coenophialum, tall fescue, water stress

\footnotetext{
*Corresponding author.

Phone) +82-63-270-2519, FAX) +82-63-270-2531

E-mail) juhojong@jbnu.ac.kr
}

Tall fescue (Schedonorus phoenix Scop. formely Festuca arundinacea Schreb.) (Henson and Safley, 2009) is a coolseason perennial grass grown as a common forage crop in the United States (Ball et al., 1996; Borrill, 1976; Buckner et al., 1979) and other countries including South America, Australia, New Zealand, China and Africa (Rudgers and Clay, 2007). The fungal endophyte, Neotyphodium coenophialum frequently infects tall fescue (Bacon and Siegel, 1988; Glenn et al., 1996) with symbiosis association commonly found in ecosystems. Since the interaction between these two organisms provides useful information to understand other mutualisms existing in grasslands, the relationship between these two organisms has received attention and been studied.

As like other endophytes (Arnold et al., 2003; Müller and Krauss, 2005), this fungal endophyte, $N$. coenophialum, enhanced resistance of tall fescue to biotic and abiotic stresses including herbivory and drought (Rudgers and Clay, 2007). Tall fescue provides nutrition and structural refuge to the endophyte, while tall fescue gets many benefits including enhanced competition (Hill et al., 1991a; 1998; Malinowski et al., 1999). Endophyte presence confers water conserving ability to tall fescue by increasing leaf rolling (Arachevaleta et al., 1989), decreasing stomatal conductance, and lower osmotic potential increasing turgor pressure (Elmi and West, 1995). In addition, fungal endophyte-infected plants have shown increased resistant plant pathogens (Siegle and Latch, 1991) and insect herbivores (Salminen et al., 2005).

Although $N$. coenophialum has great positive effect on tall fescue, this fungal endophyte has historically been considered as a negative component for animal performance (Ball et al., 1996). When animals graze endophyte infected tall fescue they consume toxic endophyte-derived ergot alkaloids resulting in reduced animal performance (Hoveland, 1993; Read and Camp, 1986). Since tall fescue toxicosis is a serious problem for the livestock industry (Bacon et al., 1986; Bush et al., 1979; Hoveland, 1993; Read and Camp, 1986), the initial management strategy to 
overcome tall fescue toxicosis was eliminating endophyte from tall fescue pasture. However, non-toxic endophytes inserted into tall fescue, can eliminate tall fescue toxicosis by replacing the old tall fescue pasture with tall fescue plants that are infected to non-toxic endophytes. Non-toxic endophytes that do not produce harmful alkaloids have been introduced into tall fescue to eliminate the toxicity to grazing animal (Gunter and Beck, 2004), but still maintain the agronomic benefit of the endophyte to host plant, tall fescue (Bouton et al., 2002). By using these non-toxic endophytes, their negative view changes more likely positive for cultivar development (Bouton et al., 2002). Therefore, endophytes in tall fescue should be considered important components for sustainable agri-ecosystem, especially in pasture.

The problem with practical deployment of non-toxic endophyte grasses is that the endophyte's mutualistic association with tall fescue is unstable resulting in occasional breakdown of mutualistic interaction (Saikkonen et al., 2004) through less vertical transmission from maternal plant to offspring (seeds). Therefore, it is essential to understand endophyte growth and transmission in tall fescue to maximize the probability of maintaining nontoxic endophytes in tall fescue pasture for better management of tall fescue pasture.

The life-cycle of fungal endophyte, Neotyphodium coenophialum, is not complicated compared to others since it has only an asexual stage without spores and spreads only vertically (Siegel et al., 1984). Bacon and Siegel (1988) reported that the endophyte grows as the seed germinates and invades the seedling plant, shortly after germination. During vegetative periods, the fungus is located in meristematic tissue of shoot apices (Bacon and Siegel, 1988). When the flowering stem begins to elongate, the mycelium grows along with the inflorescence and infects the maternal tissues of the ovule (Hinton and Bacon, 1985; Philipson and Christey, 1986).

There appears to be variation of endophyte presence and / or transmission that is association with environmental factors during plant growth. Di Menna and Waller (1986) found that the seasonal variation of mycelium concentration of Neotyphodium lolii in leaf sheaths of perennial ryegrass (Lolium perenne L.) was related to variation in mean monthly temperatures. Endophyte level decreased in seed after a hot and dry summer and cold winter (Bacon and Siegel, 1988). Temperature seems to be the most important environmental factor for these seasonal fluctuations of endophyte concentration and frequency (Ju et al., 2006). In addition, endophyte genptypes have important roles in endophyte concentration (Hiatt and Hill, 1997), resistance to herbivores (Tintjer and Rudgers, 2006), and the level of alkaloids (Hill et al., 1991b; Lane et al., 2000;
Rasmussen et al., 2007). These studies suggest that environmental variables, including water regime may affect endophyte growth and potentially vertical transmission (Gundel et al., 2011).

While the endophyte transmission process has been examined at the cellular and tissue level during seed development (Phillipson and Christey, 1986), there was lack of reports about the virtual systemic research showing the direct effect of endophyte genotype on endophyte frequency, concentration, and vertical transmission in water stressedtall fescue. Therefore, the objective of this study was to examine the effect of endophyte genotype on endophyte frequency, concentration, and vertical transmission under water stress imposed at different stages of tall fescue in greenhouse.

\section{Materials and Methods}

This experiment was carried out during the winter and early spring of 1999 to 2000 (year 1) and 2000 to 2001 (year 2) in a greenhouse located in the University of Georgia in Athens, Georgia.

Preparation of plants infected with different endophyte genotypes and water stress. Each different endophyte genotype (EDN2, EDN11, or EDN12) was previously inserted into individual germinating somatic embryo of tall fescue genotype PDN2 (Kearney et al., 1991; Royland et al., 1994) and used for this experiment. Tall fescue plants were vegetatively propagated in the greenhouse. Tillers from each were tested for endophyte presence. Two propagules of each endophyte-infected plant were randomly assigned and planted equidistant $(15 \mathrm{~cm})$ from one another in $120 \mathrm{~L}$ tubs containing $30 \mathrm{~kg}$ of fritted clay (Tidy Cat, Ralston Purina Co., St. Louis, MO). A total of nine tubs (three replicates) were planted for the experiment. Tubs containing the tall fescue plants were transferred outdoors on 1 December (1991 and 2000) and exposed to ambient growing conditions for vernalization. Tubs were irrigated with tap water as necessary to maintain soil water content. Plants were transferred back into the greenhouse on 15 February of each year (2000 and 2001). Plants were fertilized 14 days after planting and 7 days after transfer back into greenhouse with $1.27,1.27$, and $1.27 \mathrm{~g} \mathrm{tub}^{-1}$ of $\mathrm{N}$, $\mathrm{P}$, and $\mathrm{K}$ respectively. Those were randomly assigned to one of three drought stress treatments; 1) no stress, 2) stress prior to panicle emergence from the flag leaf (Before heading), or 3) stress after panicle emergence and through flowering (After heading). Soil water content (SWC) was maintained between 0.45 and $0.35 \mathrm{~g}$ water $\mathrm{g}^{-1}$ soil for the stress treatments and the non-stressed treatments were maintained at $0.65 \mathrm{~g}$ water $\mathrm{g}^{-1}$ soil (Hill et al., 1996; White 
et al., 1992). To adjust SWC, the tubs were weighed every 1-2 day and water was added to re-hydrate the soils to 0.45 $\mathrm{g}$ water $\mathrm{g}^{-1}$ soil. Leaf water potential and leaf osmotic potential were measured with pre-calibrated end-window thermocouple psychrometers (Model 85-12 V, J.R.D. Merrill Specialty Equipment Corp., Logan, UT). A single fully expanded leaf blade of each plant was excised from the youngest fully expanded leaf and a 3-4 cm section of the lamina taken immediately above the collar was placed into the thermocouple psychrometer chamber within 15 second of excision. The chambers were permitted to equilibrate in an isothermal water bath at $25^{\circ} \mathrm{C}$ for $4 \mathrm{~h}$ before measuring leaf water potential. Chambers were frozen at $-70^{\circ} \mathrm{C}$ for $2 \mathrm{~h}$, warmed to room temperature, reinserted into the water bath, and equilibrated again for $4 \mathrm{~h}$ before measuring osmotic potential. Leaf turgor pressure was calculated as the difference between osmotic potential and leaf potential. At boot stage, one plant from each plant/ endophyte combination was removed from the pots. Endophyte frequency in tiller and in floret was examined via immunoblot and endophyte contents were quantified in pseudostem via ELISA analysis. The remaining plants were harvested at the physiological maturity of the seed to examine endophyte frequency and concentration.

Endophyte frequency by immunoblot. Endophyte presence in tiller was tested using the Agrinostics Ltd. Co (Watkinsville, GA) immunoblot test kit (Hiatt et al., 1997a). A cellulose sponge was placed into a container and saturated with extraction buffer. A piece of blotting paper was placed on top of the sponge, and a piece of nitrocellulose membrane placed on top of the blotting paper. Tiller crosssections were laid on the nitro cellulose membrane. Tillers were incubated at $4{ }^{\circ} \mathrm{C}$ in a refrigerator overnight. The nitrocellulose membrane with the tillers was placed onto a dry piece of blotting paper and the stem pieces were removed. The membrane was dried at $70^{\circ} \mathrm{C}$ for 15 minutes. The membrane was placed into a container and $20 \mathrm{~mL}$ of blocking/washing solution added, and placed on an orbital shaker gyrating at $50 \mathrm{rpm}$ for 30 minutes. The blocking/ washing solution was removed. Anti-endophyte monoclonal antibodie was diluted into fresh blocking/washing solution and poured over the nitrocellulose membrane. The membrane was incubated for $1 \mathrm{~h}$. The membrane washed with blocking/washing solution twice, six minutes each. Antimouse antibody was diluted in $20 \mathrm{~mL}$ blocking/washing solution, added to the shaker for $1 \mathrm{~h}$. The anti-mouse solution was removed and washed as previously described. Protein-A with a conjugated chromophore was diluted in 20 $\mathrm{mL}$ blocking/washing solution and returned to the orbital shaker for 30 minutes. After a final wash, a chromogenic solution was added for 20 minutes. The membrane was washed twice with tap water and scored for endophyte by examining for a deep pink/red where the tiller interfaced the membrane.

Endophyte presence in seeds was tested using the Agrinostics Ltd. Co (Watkinsville, GA) immunoblot test kit. Seeds were soaked in $1.25 \mathrm{M} \mathrm{NaOH}$ for $1 \mathrm{~h}$ after which they were washed with tap water until seed no longer felt slick to the touch. Control seeds of known E+ and E- origin were also prepared. A piece of nitrocellulose membrane was prepared as previously described. The seeds were placed on the nitrocellulose membrane along with 5 seed each from the $\mathrm{E}+$ and $\mathrm{E}$ - controls and incubated at $45^{\circ} \mathrm{C}$ overnight. The remaining steps for the immunoblot were as previously described, except the chromogen used for seed stained deep blue/black and were scored accordingly.

Endophyte quantification by ELISA. Endophyte concentration was measured using ELISA (Hiatt et al., 1997b). Freeze-dried plant tissue was ground using a cyclone-type mill (Cyclotec 1093 Sample Mill, Foss Tecator Co., Sweden). Fungal proteins were extracted from $15 \mathrm{mg}$ of ground lyophilized plant tissue in $1 \mathrm{ml}$ phosphate buffered saline (PBS). The samples were mixed thoroughly and incubated for $1 \mathrm{hr}$ at room temperature. Plant tissues and buffer were centrifuged for 15 minutes at 12,000 $\mathrm{g}$ and the supernatant was transferred to a new tube. Polyethylene glycol (PEG) was added to the supernatant until PEG concentration equaled $100 \mathrm{~g} /$ liter, and refrigerated overnight at $4{ }^{\circ} \mathrm{C}$ to precipitate protein. The solution was centrifuged for 15 minutes at $12,000 \mathrm{~g}$ and the supernatant was discarded. The protein pellet was re-suspended in $250 \mu \mathrm{l}$ PBS containing $0.1 \%$ sodium dodecyl sulfate (SDS) and incubated for 5 minutes at $60^{\circ} \mathrm{C}$. The SDS solution was centrifuged for 15 minutes at $12,000 \mathrm{~g}$, and the supernatant transferred to another centrifuge tube. The supernatant was diluted 1:4 $(\mathrm{v} / \mathrm{v})$ in cold acetone $\left(-20^{\circ} \mathrm{C}\right)$ and chilled overnight at $\left(-20^{\circ} \mathrm{C}\right)$ to precipitate proteins. The solution was centrifuged for 15 minutes at $12,000 \mathrm{~g}$, the supernatant was discarded, and the protein pellet was washed with $1 \mathrm{ml}$ of cold acetone. Excess acetone was decanted and the protein pellet was dried under a stream of air. Quantification of mycelia was conducted by diluting the protein pellet $(1: 4)$ in $400 \mu$ l borate saline solution ( $\mathrm{pH} 8.5)$. Fifty $\mu \mathrm{l}$ of the solution was placed into wells of an Immulon 4 microtiter plate (Dyanatech Co., Chantilly, Virginia). After permitting the protein to anneal overnight at $4{ }^{\circ} \mathrm{C}$, the plate was washed three times with ELISA wash (1.21 g Tris, $500 \mu \mathrm{l}$ Tween 20, and $0.20 \mathrm{NaN}_{3}$ /liter distilled $\mathrm{H}_{2} \mathrm{O}, \mathrm{pH} 8.0$ ), blocked with $100 \mu \mathrm{l}$ of bovine serum albumin blocking solution $(10 \mathrm{~g}$ bovine serum albumin, $1.17 \mathrm{~g} \mathrm{Na}_{2} \mathrm{HPO}_{4}, 0.24 \mathrm{~g} \mathrm{NaH}_{2} \mathrm{PO}_{4}$, $8.20 \mathrm{~g} \mathrm{NaCl}$, and $10 \mathrm{ml}$ of $2 \% \mathrm{NaN}_{3}$ per liter distilled $\mathrm{H}_{2} \mathrm{O}$ ), and the plate was incubated for 30 minutes at $21^{\circ} \mathrm{C}$. The 
plate was washed three times with ELISA wash. Neotyphodium coenophialum-specific monoclonal antibodies from hybridoma cell line 15D7, 4H2, and 5C7 were mixed and diluted to a final antibody dilution of 1:20 in ELISA diluent (1 liter blocking solution with $500 \mu$ Tween 20). Fifty $\mu \mathrm{l}$ was added to each well and the antibodies were allowed to anneal with endophyte proteins for $2 \mathrm{hr}$ at $21^{\circ} \mathrm{C}$. The plate was washed three times with ELISA wash. Fifty $\mu \mathrm{l}$ rabbit anti-mouse antibody conjugated with alkaline phosphatase (RAM-AP) (Sigma Chemical Co., St. Louis, Missouri), was diluted 1:500 in ELISA diluent. After incubating at $21^{\circ} \mathrm{C}$ for $2 \mathrm{hr}$, the plate was washed three times with ELISA wash. Fifty $\mu 1$ of substrate solution $(1 \mathrm{~g}$ p-nitrophenyl phosphate, $0.10 \mathrm{~g} \mathrm{MgCl}_{2}$, and $96 \mathrm{ml}$ diethanolamine per liter distilled $\mathrm{H}_{2} \mathrm{O}, \mathrm{pH} 9.8$ ) was added to each well, and incubated at $21^{\circ} \mathrm{C}$. Color development was stopped after 25 minutes by adding $50 \mu \mathrm{l}$ of $3 \mathrm{M} \mathrm{NaOH}$. Optical density was measured spectrally at $405 \mathrm{~nm}$ using a BioTek EL 311 (Bio-Tek Instruments, Winooski, Vermont) microplate reader. Fungal proteins were quantified by regressing ELISA values to those of a standard dilution of purified proteins from each fungal isolate use in this experiment.

Statistical analysis. Data were analyzed by analyses of variance (SAS Institute, Cary, NC). Treatments were assigned to a randomized complete block design in which all variables were considered fixed effects. Treatment means were separated using a Fisher's protected LSD.

\section{Results}

Table 1 presents the effect of endophyte genotype and of water stress on endophyte status, endophyte frequency and endophyte concentration, at the boot stage within pseudostems of tall fescue plants. For this analysis, although there were three water stresses, no stress (control), water stress before heading, and water stress after heading, actual water stress consisted of no stress and water stress before heading because tillers were collected at boot stage. Water stress showed a significant effect on endophyte frequency of pseudostem among plant regenerants infected with endophyte genotype (EDN2, EDN11, or END12) when tall fescue was water stressed prior to influorescnence, while the effect of water stress on endophyte concentration was not significant. In contrast water stress, endophyte genotype did not affected endophyte frequency in pseudostems but endophyte genotype very significantly influenced endophyte concentration. Endophyte frequency as well as endophyte concentration significantly depended on tiller types (Table 1). There was no interaction effect between factors examined in this study for endophyte frequency and con-
Table 1. Analysis of variance for endophyte frequency and concentration in pseudostem of a tall fescue genotype (PDN2) containing three different endophyte genotype (EDN2, EDN11, or EDN12) affected by water stress and harvested at boot stage

\begin{tabular}{lccc}
\hline Source & df & $\begin{array}{c}\text { Endophyte } \\
\text { frequency }\end{array}$ & $\begin{array}{c}\text { Endophyte } \\
\text { concentration }\end{array}$ \\
\hline Water Stress (WS) & 2 & 0.0280 & 0.0803 \\
Genotype (G) & 2 & 0.8745 & 0.0001 \\
Tiller type (TT) & 1 & 0.0299 & 0.0001 \\
WS*G & 4 & 0.7086 & 0.7908 \\
WS*TT & 2 & 0.0426 & 0.1772 \\
G TT $^{*}$ WSF*T $^{*}{ }^{*}$ & 2 & 0.7798 & 0.0688 \\
\end{tabular}

Table 2. Endophyte concentration in greenhouse-grown pseudostems from regenerants of tall fescue genotype (PDN2) containing three different endophyte genotypes (EDN2, EDN11, or EDN12) when harvested at the boot stage

\begin{tabular}{|c|c|c|c|}
\hline EDN2 & EDN11 & EDN12 & ${ }^{\mathrm{a}} \operatorname{LSD}(0.05)$ \\
\hline \multicolumn{4}{|c|}{ - } \\
\hline 1.21 & 1.20 & 1.36 & 0.08 \\
\hline
\end{tabular}

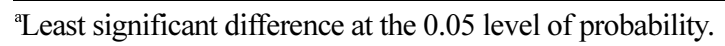

centration, except for interaction effect between water stress and tiller type on endophyte frequency but not on concentration based on ANOVA at Table 1. Differences in endophyte concentration within pseudostems from regenerants of tall fescue containing each endophyte (EDN2, EDN11, or EDN12) are presented at Table 2. Endophyte EDN12 was present at a higher concentration in pseudostems than EDN2 or EDN11 (Table 2). When tall fescue plants received water stress before heading, endophyte frequency at different tiller types differed (Table 3) with higher endophyte infection ratio at the reproductive tiller

Table 3. Interaction between water stress and tiller type on endophyte frequency in tillers of a tall fescue genotype (PDN2) containing three different endophyte genotypes (EDN2, EDN11, or EDN12) and grown in green house and harvested at the boot stage

\begin{tabular}{lccc}
\hline \hline \multirow{2}{*}{ Water treatment } & \multicolumn{3}{c}{ Tiller type } \\
\cline { 2 - 3 } & $\begin{array}{c}\text { Reproductive } \\
\text { tiller }\end{array}$ & $\begin{array}{c}\text { Vegetative } \\
\text { tiller }\end{array}$ & \\
\hline & & aSD $(0.05)$ \\
Before heading & 98.89 & 95.00 & 3.16 \\
After heading & 98.89 & 98.89 & $\mathrm{NS}$ \\
NO water stress & 99.17 & 98.61 & $\mathrm{NS}$ \\
\hline${ }^{a}$ LSD $(0.05)$ & N.S & 2.99 & \\
\hline${ }^{a}$ indicates least significant difference at the 0.05 level of probability \\
and NS indicates not significant.
\end{tabular}


Table 4. Effects of tiller type on endophyte concentrations in tillers of tall fescue tall fescue genotype (PDN2) containing three different endophyte genotypes (EDN2, EDN11, or EDN12) affected by drought stress, grown in greenhouse, and harvested at the boot stage

\begin{tabular}{lccc}
\hline \hline \multirow{3}{*}{ Tiller type } & \multicolumn{3}{c}{ Endophyte concentration (mg endophyte/plant) } \\
\cline { 2 - 4 } & $\begin{array}{c}\text { Reproductive } \\
\text { tiller }\end{array}$ & $\begin{array}{c}\text { Vegetative } \\
\text { tiller }\end{array}$ & a LSD (0.05) \\
\cline { 2 - 4 } & 1.45 & 1.06 & 0.07 \\
\hline
\end{tabular}

aindicates least significant difference at the 0.05 level of probability.

Table 5. Analysis of variance for endophyte frequency of tall fescue floret and seed affected by drought stress on tall fescue genotype (PDN2) containing different endophyte genotypes (EDN2, EDN11, or EDN12) affected by water stress harvested at boot stage and seed maturity

\begin{tabular}{lccc}
\hline \hline Source & $\mathrm{df}$ & Floret & Seed \\
\hline Water Stress (WS) & 2 & 0.2777 & 0.6025 \\
Genotype (G) & 2 & 0.0962 & 0.0782 \\
Position (P) & 2 & 0.0016 & 0.0001 \\
WS*G & 4 & 0.5264 & 0.7790 \\
WS*P & 4 & 0.7914 & 0.6400 \\
$\mathrm{G}^{*} \mathrm{P}$ & 4 & 0.4709 & 0.2813 \\
$\mathrm{WS}^{*} \mathrm{G} * \mathrm{P}$ & 8 & 0.9659 & 0.6422 \\
\hline
\end{tabular}

compared to that of vegetative tillers. There was no effect of water treatment endophyte frequency at reproductive with very high frequency almost $99 \%$ but water treatment decreased endophyte frequency at vegetative tiller (Table $3)$. Endophyte concentration in vegetative tiller and reproductive tiller was presented at Table 4. Reproductive tiller contained $1.45 \mathrm{mg}$ of endophyte per plant and vegetative tiller had $1.06 \mathrm{mg}$ of endophyte per plant, about $37 \%$ greater endophyte concentration in reproductive tiller than vegetative tiller.

ANOVA (Table 5) indicated that endophyte frequency of florets or seeds within the panicles depended on positions of them, whereas water stress and endophyte genotype did not affect endophyte frequency of florets or seeds. Florets harvested from the middle and base of the panicle had lower endophyte frequency compared to florets acquired from the top of the panicle. Seeds harvested from the middle of the panicle had lower endophyte frequency than seeds harvested at the base or top of the panicle (Table 6). In general, both florets and seeds harvested from the top showed greater endophyte frequency (Table 6). Like endophyte frequency, there was also no drought effect on endophyte concentration, but there were effects of endophyte genotype on endophyte concentration in seeds (Table 7). Plants infected with endophyte genotype EDN12 contained higher endophyte concentration in seeds collected from tall
Table 6. Endophyte frequency in florets or seeds of regenerants of tall fescue genotype PDN2 containing three different endophyte genotypes EDN2, EDN11, or EDN12. Plants were grown in the greenhouse and harvested at boot stage and seed maturity

\begin{tabular}{lcccc}
\hline \hline \multirow{2}{*}{ Seed stage } & \multicolumn{3}{c}{ Panicle position } & \\
\cline { 2 - 4 } & Top & Middle & Bottom & \\
\hline \multicolumn{1}{c}{ aret } & 62.15 & 55.11 & 55.48 & 4.25 \\
Floret & 69.89 & 59.70 & 65.74 & 4.47 \\
\hline
\end{tabular}

${ }^{a}$ Least significant difference at the 0.05 level of probability.

Table 7. Analysis of variance for endophyte concentration in floret or seed of tall fescue genotype (PDN2) containing different endophyte genotypes (EDN2, EDN11, or EDN12) affected by drought stress at seed maturity

\begin{tabular}{lcc}
\hline \hline Source & df & Seed \\
\hline Water Stress (WS) & 2 & 0.8015 \\
Genotype (G) & 2 & 0.0500 \\
WS*G & 4 & 0.9685 \\
OT(Organ type) & 1 & 0.0001 \\
WS*OT & 2 & 0.6427 \\
G OT $^{*}$ & 2 & 0.2736 \\
WS*G*OT & 4 & 0.9817 \\
\hline
\end{tabular}

Table 8. Endophyte concentration at panicle of tall fescue genotype (PDN2) containing three different endophyte genotypes (EDN2, EDN11, or EDN12) and grown in greenhouse at seed maturity

\begin{tabular}{lcccc}
\hline \hline Organ & EDN2 & EDN11 & EDN12 & ${ }^{\mathrm{a}} \mathrm{LSD}(0.05)$ \\
\hline Floret & 0.32 & 0.30 & 0.38 & 0.04 \\
Seed & 1.34 & 1.48 & 1.72 & 0.18 \\
\hline
\end{tabular}

andicates least significant difference at the 0.05 level of probability

fescue compared to tall fescue plants with endophyte genotype EDN2 or EDN11 (Table 8). In addition, endophyte concentration was dependent on organ type (Table 7 and 8). Overall endophyte concentration in seeds was approximately 5 times higher than that of floret.

\section{Discussion}

It is essential to have information about endophyte vertical transmission from maternal plant to better maintain nontoxic endophytes in tall fescue pasture. Knowledge of endophyte frequency and concentration in tall fescue plants will provide information to understand symbiotic relationships in pasture ecosystems.

Previous studies revealed that there were seasonal variations on endophyte biomass and frequency in perennial 
ryegrass Di Menna and Waller (1986) and tall fescue Ju et al. (2006) grown under field conditions. They found fewer mycelia or less endophyte frequency in pseudostem tissue during winters in the Southern and Northern Hemisphere. Seed and vegetative tissue of tall fescue after the plants experienced hot and dry summers and cold winters showed decreased endophyte frequency (Bacon and Siegel, 1988). Ju et al. (2006) showed that endophyte biomass in tall fescue depended on minimum cardinal temperatures playing a key role as environmental factor controlling these seasonal variations of endophyte concentration and frequency. These all indicate that the seasonal variability of the endophyte resulted from seasonal variation of temperature and water dynamics. Although it had been suggested that endophyte frequency or concentration in endophyteinfected plants may be associated to the plant genotypes or endophyte genotypes (Hiatt and Hill, 1997; Hill et al., 1991b), there was lack of report about the virtual systemic research linking endophyte frequency or concentration in tall fescue to endophyte genotype and water dynamics.

Water stress affected endophyte frequency but not concentration in pseudostems of tall fescue (Table 1). Endophyte frequency depended on the interaction between water stress and tiller type (Table 1). This interaction may explain the reason less endophyte frequency was shown at Table 3. Less endophyte frequency in vegetative tiller (Table 3 ) is more likely an effect of drought stress on vegetative tiller limiting resources available for the endophyte rather than a direct effect on the endophyte. Vegetative tillers, relatively younger tissues than reproductive tillers, are generally more susceptible to water deficiency than reproductive tiller (Mostajeran and Rahimi-Eichi, 2009). Mycelium of endophyte within established seedlings generally grows into new tillers (Bacon and Siegel, 1996). Lower rates of endophyte transmission correlated to less biomass of host plant meaning limited resources affect endophyte transmission in tall fescue because of the cost requirement for endophyte establishment (Cheplick, 2004; Mack and Rudger, 2008). Although the endophyte enhanced tall fescue performance in drought conditions, endophyte infection of tall fescue may be a disadvantage in terms of host growth and in reduced resource availability for endophyte growth. It was suspected that reduced resources resulted in low endophyte transmission (Gundel et al., 2011a; 2011b; Mack and Rudger, 2008). Endophytes in reproductive tillers were established before resources were reduced. However, many of the vegetative tillers were established while tall fescue encountered drought stress, resulting in reduced available resources to the endophyte in vegetative tillers (Table 3). This might affected less endophyte frequency showed with low concentration of endophyte in vegetative tiller under drought stress compared to that of reproductive tiller with high concentration in the same water regime (Table 4). Previous study conducted in vitro (Bruehl and Kaiser, 1996) partially supported low endophyte frequency and concentration in vegetative tillers. Endophytes grew well on agar media amended with osmoticum to obtain water potential of $-3 \mathrm{MPa}$, equivalent to quite bit drought stress (Bruehl and Kaiser, 1996). In other words, once the endophyte is established in host plants, endophyte frequency is not affected by water stress.

It had been known that the endophyte resides within meristematic tissue during vegetative growth (Bacon and Siegel, 1988; Sampson, 1933; 1937) and that endophytes are in flower primodia before development of inflorescences (Siegel et al., 1985). Hinton and Bacon (1985) suggest that an infected bud simply outgrows the endophytes when conditions are not favorable for the endophyte. Thus, it is vital for endophytes to invade or to ramify developing seeds as a possible means to avoid maintaining rapid growth rates during elongation of the culm. Endophyte has been observed in the differentiating primodial tissue prior to stem elongation (Phillipson and Christy, 1986). It is likely the endophyte prioritizes invasion of the developing floret over other tissue, perhaps when vernalization conditions have been met before drought stresses. Since endophyte in planta is non-septate (Hinton and Bacon, 1985), it is possible the endophyte transports vital components back to the meristematic region to provide necessary nutrients to sustain growth and invasion of the developing panicle primodia even throughout drought conditions. These observations partially explain the other reason that drought did not affect endophyte frequency and endophyte concentration within tall fescue floret and seed (Table 5 and 7). In this study, the drought experiments combination with endophyte genotype showed little or no effect of drought on seed transmission of endophyte but showed effect of endophyte genotype on endophyte concentration in pseudostem (Table 2) and in florets and seeds (Table 8). Endophyte genotype (EDN12) showed higher endophyte concentration in pseudostem at boot stage (Table 2) and resulted in higher endophyte concentration in two different organs, florets and seeds, on a panicle. These results were supported by previous research (Philipson and Christey, 1986). Seed transmission of this fungal endophyte from an infected maternal plant very closely relates their interactions through their life cycles. The experiment conducted by Philipson and Christey (1986) indicated that the endophyte should produce great amounts of endophyte hyphae before boot stage and must transmit into the developing embryos to infect the seeds.

There was an interesting result that endophyte frequency in florets or seeds varied along the panicle showing high endophyte frequency in seed and in the floret located at top position of panicle. This phenomenon maybe related with 
seed maturity. Once the endophytes spread into the seeds, endophyte multiplication and its persistence in seed depend on its ability to remain viable during seed development. Hill et al. (2005) presented that the different harvesting time of tall fescue seed resulted in various endophyte frequency, noting that seed containing late embryogenesis abundant (LEA) protein which prevents embryo death may also provide endophyte protection during very low water potential at seed maturation. As described earlier, limited resources led to failure of endophyte transmission. Based on Gundel et al. (2011b) fungal endophyte transmission from plant to seed is regulated by host plant fitness showing that high seed yielding host plants had higher vertical transmission of endophyte because of enough resources available for endophyte growth. In general, top positioned seeds in a panicle are heavier than seeds located at other positions because they developed a longer time resulting in more stored energy. Endophyte infection is an energy requiring process (Cheplick, 2007). They suggested that top positioned seeds maybe provide more energy to endophyte compared to seeds in other positions.

From this study, we can conclude that although water stress reduced endophyte frequency in vegetative tillers, water stress does not have effect on endophyte vertical transmission suggesting that water stress is not an important factor controlling the endophyte transmission from maternal plant to seed. Endophyte genotype and seed position in a panicle affected endophyte vertical transmission indicating that these two factors are involved in endophyte vertical transmission and may determine seed transmission of this fungal endophyte. This could be an important finding to scientists to increase understanding of microbe-host symbiosis in grass ecosystem. Likewise, it provides rationale for tall fescue seed producers to determine the endophyte genotype they have or make specific selection of one that will maintain high levels of non-toxic endophyte in their seed, and maximize the probability of maintaining nontoxic endophyte in pasture.

\section{References}

Afkhami, M. E. and Rudgers, J. A. 2008. Symbiosis lost: imperfect vertical transmission of fungal endophytes in grasses. American Naturalist 172:405-416.

Arachvaleta, M., Hoveland, C. S., Bacon, C. W. and Radcliffe, D. E. 1989. Effect of the tall fescue endophyte on plant response to environmental stress. Agron. J. 81:83-90.

Arnold, E. A., Mejia, L. C., Kyllo, D., Rojas, E. I., Maynard, Z., Robbins, N. and Herre, E. A. 2003. Fungal endophyts limit pathogen damage in a tropical tree. Proc. Natl. Acad. Sci. U.S.A. 100:15649-15654.

Bacon, C. W. and Siegel, M. R. 1988. Endophyte parasitism of tall fescue. J. Prod. Agric. 1:45-55.

Bacon, C. W., Lyons, P. C., Porter, J. K. and Robbins, J. K. 1986. Ergot Toxicity from endophyte-infected grasses. Agron. J. 78: 106-116.

Ball, D. M., Hoveland, C. S. and Lacefield, G. D. 1996. Cool seasonal grass. In: Southern Forages, ed D.M. Ball, C.S. Hoveland and G.D. Lacefield, pp. 41-48. The Potash \& Phosphate Institute (PPI) and the Foundation for Agronomic Research (FAR). Norcross, GA, USA.

Borrill, M., Tyler, B. F. and Morgan, W. G. 1976. Studies in Festuca 7. Chromosome atlas (part 2). An appraisal of chromosome race distribution and ecology, including $F$. pratensis var.Apennina (De Not.) Hack., -tetraploid. Cytologia 41:219236.

Bouton, J. H., Latch, G. C., Hill, N. S., Hoveland, C. S., McCann, M. A., Watson, R. H., Parish, J. A., Hawkins, L. L. and Thompson, F. N. 2002. Reinfection of tall fescue cultivars with non-ergot alkaloid-producing endophytes. Agron. J. 94: 567-574.

Bruehl, G. W. and Kaiser, W. J. 1996. Some effects of osmotic water potential upon endophytic Acremonium spp. in culture. Mycologia 88:809-815.

Bucker, R. C., Powell, J. B. and Frakes, R. V. 1979. Historical development. In: Tall Fescue. ed. by C.R. Buckner and L.P. Bush, pp. 1-8. Agron. Monogr. 20. ASA, Madison, WI.

Bush, L. P., Boling, J. A. and Yates, S. G. 1979. Animal disorder. In: Tall Fescue. ed. by C.R. Buckner and L.P. Bush, pp. 247292. Agron. Monogr. 20. ASA, Madison, WI.

Cheplick, G. 2004. Recovery from drought stress in Lolium perenne (Poaceae): are fungal endophytes detrimental? Am. J. Bot. 91:1960-1968.

Cheplick, G. 2007. Cost of fungal endophyte infection in Lolium perenne genotypes from Eurosia and North America under extreme resource limitation. Environ. Exp. Bot. 60:202-210.

Di Menna, M. E. and Waller, J. E. 1986. Visual assessment of seasonal changes in amount of mycelium of Acremonium loliae in leaf sheaths of perennial ryegrass. N.Z. J. Agric. Res. 29: 111-116.

Elmi, A. A. and West, C. P. 1995. Endophyte infection effects on stomatal conductance, osmotic adjustment and drought recovery of tall fescue. New Phytol. 131:61-67.

Glenn, A. E., Bacon, C. W. Price, R. and Hanlin, R. T. 1996. Molecular phylogeny of Acremonium and its taxanomic implications. Mycologia 88:369-383.

Gundel, P. E., Rudgers, J. A. and Ghersa C. M. 2011a. Incorporating the process of vertical transmission into understanding of host-symbiont dynamics. Oikos doi:10.1111/j.16000706.2011.19299.x

Gundel, P. E., Garibaldi, L. A., Martínez-Ghersa, M. A. and Ghersa, C.M. 2011b. Neotyphodium endophyte transmission to Lolium multiflorum seeds depends on the host plant fitness. Environ. Exp. Bot. 71:359-366.

Gundel, P. E., Garibaldi, L. A., Tognetti, P. M., Aragón, R., Ghersa, C. M. and Omacini, M. 2009. Imperfect vertical transmission of the endophyte Neotyphodium in exotic grasses in grasslands of the Flooding Pampa. Microbial. Ecol. 57:740- 
748.

Gunter, S. A. and Beck, P. A. 2004. Novel endophyte-infected tall fescue for growing beef cattle. J. Anim. Sci. 82(E. Suppl): E75-E82.

Henson, J. and Safley, M. 2009. NRCS plant information and conservation practice standards. In: Tall fescue monograph. http:// forages.oregonstate.edu/tallfescuemonograph/NRCS/databa se (accessed July 6, 2011).

Hiatt, III, E. E. and. Hill, N. S. 1997. Neotyphodium coenophialum mycelia protein and herbage mass effects on ergot alkaloid concentration in tall fescue. J. Chem. Ecol. 23:27212736.

Hiatt, III, E. E., Hill, N. S. and Bouton, J. H. 1997a. Tissue immunoblot procedure for detection of Neotyphodium coenophialum in tall fescue. In: Neotyphodium/Grass interactions. ed. by C.W. Bacon and N.S. Hill, pp. 265-266. Plenum New York, NY.

Hiatt, III, E. E., Hill, N. S., Bouton, J. H. and Mims, C. W. 1997b. Monoclonal antibodies for detection of Neotyphodium coenophialum. Crop Sci. 37:1265-1269.

Hill, N. S., Belesky, D. P. and Stringer, W. C. 1991a. Competitiveness of tall fescue as influenced by endophyte. Crop Sci. 31: 185-190.

Hill, N. S., Belesky, D. P. and Stringer, W. C. 1998. Encroachment of endophyte on endophyte-free tall fescue. Ann. Bot. 81:483488.

Hill, N. S., Pachon, J. G. and Bacon, C. W. 1996. Acremonium coenophialum mediated short and long -term drought acclimation in tall fescue. Crop Sci. 36:665-672.

Hill, N. S., Parrott, W. A. and Pope, D. D. 1991b. Ergopeptine Alkaloid Production by Endophytes in a Common Tall Fescue Genotype. Crop Sci. 31:1545-1547.

Hinton, D. M. and Bacon, C. W. 1985. The distribution and ultrastructure of the endophyte of toxic tall fescue. Can. J. Bot. 63:36-42.

Hoveland, C. S. 1993. Importance and economic significance of the Acremonium endophytes to performance of animals and grass plant. Agric. Ecosyst. Environ. 44:3-12.

Ju, H.-J., Hill, N. S. Abbott, T. and Ingram, K. T. 2006. Temperature influences on endophyte growth in tall fescue. Crop Sci. 46:404-412.

Kearney, J. F. Parrot, W. A. and Hill, N. H. 1991. Infection of somatic embryos of tall fescue with Acremonium coenophialum. Crop Sci. 31:979-984.

Lane, G. A. Christensen, M. J. and Miles, C. O. 2000. Coevolution of fungal endophytes with grasses: the significance of secondary metabolites. In: Microbial Endophytes. ed. by C.W. Bacon and J.F. White, pp. 341-388. Marcel Dekker, New York, NY, USA.

Mack, K. M. L. and Rudger, J. A. 2008. Balancing multiple mutualists: asymmetric interactions among plants, arbuscular mycorrhizal fungi, and fungal endophytes. Oikos 117:310-320.

Malinowski, D. P., Brauer, D. K. and Belesky, D. P. 1999. The endophyte Neotyphodium coenophialum affects root morphology of tall fescue grown under phosphorus deficiency. $J$. Agron. Crop Sci. 183:53-60.
Mostajeran, A. and Rahimi-Eichi, V. 2009. Effects of drought stress on growth and yield of rice (Oryza sativa L.) cultivars and accumulation of proline and soluble sugars in sheath and blades of their different ages leaves. American-Eurasian $J$. Agric. Environ. Sci. 5:264-272.

Müller, C. B. and Krauss, J. 2005. Symbiosis between grasses and asexual fungal endophytes. Curr. Opin. Plant Biol. 8:450-456.

Neil, J. C. 1941. The endophytes of Lolium and Festuca. N.Z. J. Sci. Technol. 23(Series A):185-193.

Philipson, M. N. and Christey, M. C. 1986. The relationship of host endophyte during flowering, seed formation, and germination of Lolium perenne. N. Z. J. Bot. 24:125-134.

Rasmussen, S., Parsons, A. J., Bassett, S., Christensen, M. J., Hume, D. E., Johnson, L. J., Johnson, R. D., Simpson, W. R., Stacke, C., Voisey, C. R., Xue, H. and Newman, J. A. 2007. High nitrogen supply and carbohydrate content reduce fungal endophyte and alkaloid concentration in Lolium perenne. New Phytol. 173:787-797.

Read, J. C. and Camp, B. J 1986. The effect of the fungal endophyte Acremonium Coenophialum in tall fescue on animal performance, toxicity, and stand maintenance. Agron. J. 78:848850.

Roylance, J. T., Hill, N. S. and Parrot, W. A. 1994. Detection of somatic variation in tissue culture regenerants of tall fescue. Crop Sci. 34:1369-1372.

Rudgers, J. A. and Clay, K. 2007. Endophyte symbiosis with tall fescue: how strong are the impacts on communities and ecosystems?. Fungal Biosys. Rev. 21:107-124.

Saikkonen, K., Wäli, P., Helander, M. and Faeth, S. H. 2004. Evolution of endophyte-plant symbioses. Trends Plant Sci. 9: 275-280.

Salminen, S. O., Richmond, D. S., Grewal, S. K. and Grewal, P. S. 2005. Influence of temperature on alkaloid levels and fall armyworm performance in endophytic tall fescue and perennial ryegrass Entomol. Exp. Appli. 115:417-426.

Sampson, K. 1933. The systemic infection of grasses by Epicholoe typhina (Pers.). Trans. Br. Mycol. Soc. 18:30-47.

Sampson, K. 1937. Further observations on the systemic infection of Lolium. Trans. Br. Mycol. Soc. 21:84-97.

Siegel, M. R. and Latch, G. C. M. 1991. Expression of fungal activity in agar culture byisolates of grasses. Mycology 69: 179-183.

Siegel, M. R., Johnson, M. C. Varney, D. R., Nesmith, W. C., Buckner, R. C., Bush, L. P., Burrus, P. B. II., Jones, T. A. and Boling, J. A. 1984. A Fungal endophyte in tall fescue: Incidence and dissemination. Phytopathology 74:932-937.

Siegel, M. R., Latch, G. C. M. and Johnson, M. C. 1985. Acremonium fungal endophytes of tall fescue and perennial ryegrass: Significance and control. Plant Dis. 69:179-183.

Tintjer, T. and Rudgers, J. A. 2006. Grass-herbivore interactions altered by strains of a native endophyte. New Phytol. 170: 513-521.

White, R. H., Engelke, M. C., Morton, S. J. and Ruemmele, B. A. 1992. Competitive turgor maintenance in tall fescue. Crop Sci. 32:251-256. 